DOI https://doi.org/10.30525/978-9934-26-110-7-11

\title{
ПОСТЧЕЛОВЕЧЕСКОЕ БУДУЩЕЕ ГЛАЗАМИ РОДЖЕРА ЖЕЛЯЗНЫ
}

\author{
Донец П. Н. \\ преподаватель кафедры романо-германской филологии и методики \\ преподавания иностранных языков \\ Международный гуманитарный университет \\ 2. Одесса, Украина
}

Может сложиться впечатление, что тематика трансгуманизма в научно-фантастической литературе - веяние недавнего времени, а проблема постчеловеческого будущего возникает в произведениях лишь современных писателей. Тем интереснее обнаруживать, что это далеко не всегда так: при более пристальном рассмотрении признаки упомянутой докритны в изобилии встречаются и у авторов XX века.

Одним из них, бесспорно, является американский писатель польского происхождения Р. Желязны - фантаст с мировым именем, выделяющийся даже на фоне ближайших коллег по жанру. Широкому кругу читателей он известен в первую очередь как создатель фэнтезийной эпопеи «Хроники Амбера», но при этом ему одинаково хорошо удавались и научно-фантастические сюжеты. Сам Желязны по этому поводу заметил: «Я часто пытался понять, кем я являюсь - писателем, пишущим научную фантастику, которому снится, что он пишет фэнтези, или наоборот» [5, с. 437].

Трансгуманистичность творческого наследия рассматриваемого автора в известной степени противоречива и неоднозначна. С одной стороны, очевидно его неравнодушие к теме иммортализма. Как отмечает К. Йок, есть несколько систематически повторяющихся тем в произведениях Желязны и бессмертие стоит в этом списке на первом месте [7, p. 15]. С другой стороны, сама идея трансгуманизма, похоже, не нашла в душе писателя соответствующего отклика, а социальнопсихологические последствия её реализации виделись ему преимущественно в чёрно-серых тонах.

Так, героем рассказа «Вечная мерзлота» выступает заточенное на ледяной планете постчеловеческое создание - оцифрованная личность, загруженная в систему автоматического контроля жизнеобеспечения. Не похоже, однако, чтобы могущественный, но ограниченный в физиологическом плане бестелесный ум ощущал себя хоть сколько- 
нибудь счастливым: напротив, лишь одиночество и отчаяние являются его единственными спутниками [1, с. 237].

В психологическом детективе «Возвращение палача» читатель знакомится с постчеловеком в облике машины. Впрочем, при всей своей высокоорганизованности, искусственному интеллекту не удалось избежать недостатков его создателей: как указывает сам автор, в нём «отражалась раздробленность и противоречия, свойственные человеческой личности» [2, с. 371].

К числу постлюдей, очевидно, относится и надменный киборг из рассказа «Получеловек», «способный напрямую соединяться с любой системой своего корабля» [4, с. 412]. Отмеченный навык делает из него идеального покорителя космоса, одним своим строением нивелирующего грань между органикой и машиной. Но даже самые продвинутые технологии не сделали его более счастливым, добросердечным и располагающим к себе созданием.

Прохладное отношение Желязны к идеям трансгуманизма отчётливо проявляется в повести «Кладбище слонов». Концепция иммортализма встречает здесь осуждение, а перспективы крионики вызывают неприкрытый скепсис [3, с. 216]. Богатые и знаменитые покупают себе вечную молодость за счёт достижений науки, вследствие чего большую часть своей жизни они проводят в состоянии анабиоза и просыпаются лишь на несколько недель в году, чтобы предаться развлечениям, спонтанным эмоциям, взаимным симпатиям и антипатиям. Перед глазами зрителей предстаёт богема, ставшая жертвой замкнутой элитарности, живущая яркой, но бессмысленной жизнью, растянутой с помощью анабиоза на столетия вечного праздника, который обычные смертные воспринимают как развлекательное шоу.

Примером проявления имморталистической позиции у Желязны является роман «Этот бессмертный». Земля, превратившаяся в результате ядерной войны в туристический заповедник для инопланетян, усилиями горстки людей пытается избежать порабощения пришельцами. Главный герой, его символическая смерть и воскрешение означает восстановление радиоактивной Земли, её перестройку для землян и руками землян, что даёт человечеству надежду на возрождение, справедливо указывает Дж. Франкавилла [6, р. 214].

Высокую ценность в трансгуманистическом контексте представляет роман «Создания света, создания тьмы». Оригинально сплетая футуристические технологии с элементами фэнтези, Желязны описывает мир, где балом правит синтез технологии и магии. Неограниченные реинкарнации с помощью технических средств, люди, уподобившиеся 
богам и не привязанные к единственному телу - всё это, без сомнения, может расцениваться как мир победившего трансгуманизма и морфологической свободы.

Затейливой амальгамой трансцендентального трансгуманизма и концепции парадайз-инжиниринга является роман «Князь света», иллюстрирующий извечное противостояние между трансформирующим познанием с одной стороны и застойным реакционизмом - с другой. В результате освоения далёкой планеты среди колонизаторов выделилась небольшая группа людей, которые, узурпировав все технологии, причислили себя к божественной касте, а остальных обрекли на выживание в суровых условиях. Как следствие, избранные стали вести богоподобный образ жизни в искусственно поддерживаемой райской биосферной среде, став практически бессмертными; остальное же население планеты брошено выживать в условиях Средневековья.

Как видим, творческое наследие Желязны наглядно иллюстрирует известный тезис о том, что высокие технологии - меч обоюдоострый. Не возникает сомнений, что дальнейшее исследование его произведений с позиций лингвистики и философии, обнаружит ещё много интересного и неизведанного.

\section{Литература:}

1. Желязны Р. Вечная мерзлота. Миры Роджера Желязны. Рига: Полярис, 1995. Т. 14. С. 226-252.

2. Желязны Р. Возвращение палача. Миры Роджера Желязны. Рига: Полярис, 1995. Т. 10. С. 338-398.

3. Желязны Р. Кладбище слонов. Миры Роджера Желязны. Рига: Полярис, 1995. Т. 11. С. 213-274.

4. Желязны Р. Получеловек. Muры Роджера Желязны. Рига: Полярис, 1995. Т. 13. С. 409-414.

5. Желязны Р. Фэнтези и научная фантастика: взгляд писателя. Mupbl Роджера Желязны. Рига: Полярис, 1995. Т. 14. С. 437-444.

6. Francavilla J. V. Promethean Bound: Heroes and Gods in Roger Zelazny's Science Fiction. The Transcendent Adventure: Studies of Religion in Science Fiction/Fantasy. Westport: Greenwood Press, 1985. pp. 207-222.

7. Yoke C. B. Roger Zelazny. West Linn: Starmont House, 1979. 111 p. 